脳腫瘍分類の歴史とWHO2016 における神経膠腫診断の重要性

杉山一彦

広島大学病院がん化学療法科

\title{
An Overview of the History of Brain Tumor Classification and Glioma Diagnosis in WHO2016
}

\author{
Kazuhiko Sugiyama, M.D. \\ Department of Clinical Oncology \& Neuro-oncology Program, Hiroshima University Hospital
}

The WHO classification of central nervous system tumors has been published and revised based on the entities established by well-known morphological researchers such as Harvey W. Cushing and Lucien J. Rubinstein. Recently, the molecular information about these tumors has accumulated enormously, and so the need for the classification to include, reflect, and be based on this molecular information has increased. Accordingly, WHO is establishing a new classification in May, 2016, and the main concept is an integrated diagnosis consisting of three diagnostic points: histopathology, WHO grading, and molecular information. According to the new classification, adult diffuse gliomas will be separated into two categories of astrocytoma and oligodendroglia depending on the status of IDH \& ATRX gene mutation and $1 \mathrm{p} / 19 \mathrm{q}$ co-deletion, while the entity of oligoastrocytoma is no longer adopted because of the wide diagnostic discrepancy between morphological observations and the mutually exclusive molecular characteristics of astrocytic and oligodendroglial tumor cells.

(Received April 18, 2016 ; accepted May 12, 2016)

Key words : brain tumor classification, WHO2016, integrated diagnosis

Jpn J Neurosurg (Tokyo) $25: 542-547,2016$

\section{はじめに}

2007 年に第 4 版として改定されたWHO 脳腫瘍分類 (以下WHO2007) は今年 2016 年に up-date 予定である ${ }^{12)}$. これは本来であれば改定第 5 版とするべき大幅な変更で あるが, 他の腫瘍分類が第 4 版改定作業中の分野も多く, WHO 腫瘍分類全体の作業過程を統一する意味もあり, 第 4 版 up-date という立ち位置になっている ${ }^{12)}$. 逆にそ れほど脳腫瘍分類が遺伝子診断を基盤として大きく変貌 し，臨床面に大きく影響しつつあることを示している。 WHO 脳腫瘍分類第 4 版 up-date（WHO2016）改定の
要である Massachusetts General Hospital 病理学 David N. Louis は改定に臨む姿勢を示した論文を「“Let us now praise famous men” ‥or molecules?」と題して，2012 年 に発表している ${ }^{11)}$ 。この表題は世界恐慌下, 米国南部農 民の姿を撮り続けた写真家Walker Evansの写真集のタイ トルを引用しており ${ }^{1)}$, 「名高き人々 または 名高き分 子たち いざ称えん」と訳すことができようか.この論 文の中で彼は「WHO2007 までは著名な形態学者が確立 してきた脳腫瘍の疾患概念をWHO2016では遺伝子・分 子診断に基づき再分類する」ことを宣言している。

本稿ではWHO2007 までの作成過程を famous menの関

\footnotetext{
連絡先：杉山一彦，干 734-8551 広島市南区霞 1-2-3, 広島大学病院がん化学療法科

Address reprint requests to: Kazuhiko Sugiyama, M.D., Department of Clinical Oncology \& Neuro-oncology Program, Hiroshima University Hospital, 1-2-3 Kasumi, Minami-ku, Hiroshima-shi, Hiroshima 734-8551, Japan
} 
わりから概観し，WHO2016 の改定骨子を神経膠腫に題 材を絞って解説する。

\section{脳腫瘍分類の歴史}

脳腫瘍の形態学診断の歴史は 18 世紀後半のドイッ産 業革命での化学物質の合成技術の進歩と Rudolf L. K. Virchow（1821～1902）らの登場により診断基盤が確立し, 薄切標本を染色し, 顕微鏡で観察する時代に入った ${ }^{3)}$. この時代, 染色法はまさに古典的で, ヘマトキシリン \& エオジン（H＆ E）染色と細網線維染色, 神経突起を観 察する鍍銀染色等の組み合わせで診断していた ${ }^{3)}$.

20 世紀に至り，特記すべき分類法・命名法が登場す る. Baily \& Cushing の脳腫瘍分類である ${ }^{18)}$ 。これは脳腫 瘍を中枢神経系の発生過程に出現する細胞形態と対比し て分類したものである。神経膠腫の 3 亜型 astrocytoma, oligodendroglioma, ependymoma はこの分類で提唱され たものである.さらに,この分類で登場し, WHO2007ま で用語として残っているものは astrocytoma, glioblastoma (multiforme), oligodendroglioma, ependymoma, astroblastoma, medulloblastoma, ependymoblastoma 等で あり，その数は大変多い. Harvey W. Cushing（1869〜 1939）の形態診断への造詣の深さと命名法の巧みさに驚 かされる.

第2次世界大戦後, 神経膠腫の概念がより明確となり, Mayo Clinic の病理医 James W. Kernohan (1896〜1981) は 神経膠腫を病理悪性度に基づき grade $1 / 2 / 3 / 4$ に分類し $た^{18)}$ 。核異型や壊死，血管内皮の増勢などにもとづいた 悪性度を決定した。また，彼の名前は Kernohan's notch として後世に引き継がれている。

その後, 脳腫瘍病理分類は「大御所の時代」を迎える. 概ね 1960１990 年代前半がその時代である。この時代 の代表的な分類は Russell \& Rubinstein や Zülch の教科書 と呼ばれるものに記載されている ${ }^{16) 20)}$. Lucien J. Rubinstein（1924〜1990）や Klaus J. Zülch（1910～1988）ら著 名な病理学者は全世界から送られてくる数多くの症例 (consultation case) を形態学的に診断して，その経験か ら脳腫瘍の分類を行っていた。形態学者の「目」が優先 された時代といえよう。同時期に免疫組織化学染色や電 子顕微鏡観察の応用が始まった ${ }^{3{ }^{318}}$. Glial fibrillary acidic protein 免疫組織化学染色と電子顕微鏡で観察される中 間系フィラメントの相関を astrocytomaの分類へ応用し, 細胞間接着装置や cilia の電子顕微鏡像と epithelial membrane antigen の免疫組織化学染色での発現が ependymoma に㧍ける診断に応用された ${ }^{17)}$. この時代を象徵す
る病理医の Lucy B. Rorke Adams（1931〜）と Lucien J. Rubinstein の象徵的な逸話が残されている.

1983 年, Rorke らは中枢神経系の未分化神経上皮腫瘍 (いわゆる blue tumor)を一括して primitive neuroectodermal tumor（PNET）と総称することを提唱した。さらに 主な分化傾向を neuronal/glial/ependymal/not other specified（NOS）の 4 分類とし, PNETの後に付記する こととした ${ }^{14)}$. 胎児性腫瘍の発生頻度はきわめて低く, また，当時取り組みが緒に就いたばかりの prospective study への症例登録にも大変好都合だったため, この提 案は臨床, 特に neuro-oncology の分野で急速に定着し た"

一方, Rubinstein らは Baily \& Cushing の分類を踏襲し ていた。胎児性腫瘍は中枢神経系の発生過程でそれぞれ の起源細胞が腫瘍化することにより発生するもので，形 態学的特徵とそれに対応する分化能力を内在するとし て，Rorke らの提案に異を唱えた ${ }^{15)}$. 1988 年ヒュースト ン, 1990 年チューリッヒでそれぞれ開催された WHO 脳 腫瘍分類の consensus meeting で 2 人は PNET の概念に ついて激しい論戦を展開した5).

結局 WHO1994ではPNETの名称は medulloblastoma と ほぼ同義語として用いられ，medulloepithelioma，ependymoblastoma, neuroblastoma が PNET と同格に扱われ ることとなった ${ }^{8)}$ 。その後，疾患概念としてのPNET は supratentrial PNETとして命脈を保っていたが1013), WHO2016 では中枢神経系 PNET の entity は削除される 予定である ${ }^{12)}$ 。一方で, atypical teratoid/rhabdoid tumor の概念は継続されるものの, ependymoblastoma, medulloepithelioma は廃止され，さらには embryonal tumors with abundant neuropils and true rosettes 等を一括 するかたちで embryonal tumor with multilayered rosettes の概念が採用され，分子診断に従った亜分類が付加され る予定となっている.

「大御所の時代」の終了とともに, 1994 年, WHO 脳腫 瘍分類第 2 版（WHO1994）が出版されることとなる.

\section{WHO 脳腫瘍分類の歴史}

WHO 脳腫瘍分類第 1 版は 1979 年に出版された $(W H O 1979)^{19)}$ 。1956 年, WHO が設立した全身の病理診 断や診断用語に関する executive boardに端を発し，その 後, 脳腫瘍に関する consultation board が徐々に形成さ れ，ここで検討症例をもとに Histological Typing of Tumours of the Central Nervous System の表題で出版され た ${ }^{17)}$. H \& E 染色時代の古典的分類のアトラスであり, 
「大御所」の息吹を感じることができる，また，WHO2007 分類まで引き継がれている組織横断的臨床像を反映する grading 法（WHO grading）を脳腫瘍分野でも行うことを 明言した点で意義深い ${ }^{17)}$.

第 2 版は 1994 年に出版された $(\text { WHO1994 })^{8) 17)}$. Glioblastoma multiformeの用語は廃止し, glioblastomaの名称 に統一さ机た。グリア系，神経系，上皮系を認識する抗 体を用いた免疫組織化学染色が注目されるが，B5 版 100 頁の小冊子であり, 各項目数行の解説文の前半部, 顕微鏡写真の後半部の構成からなり, そのインパクトは あまり高いものではなかった。

第 3 版は 2000 年に出版された $(\text { WHO2000 })^{9) 17)}$. 表題 名は Pathology \& Genetics Tumours of the Nervous System と 変更され, A4版となり, 各章数名からなる working group が構成され，分担執筆制が導入された。また，文献引用 が非常に精緻に行われたことも特徵である。遺伝子変異 の記載も加えられた。神経膠腫は astrocytic tumor, oligodendroglial tumor, mixed tumor (oligoastrocytoma に相 当), ependymal tumor に分類されている.

第 4 版は 2007 年に出版された $\left(\right.$ WHO2007) $\left.{ }^{10)}{ }^{17}\right)$. 表題 名は WHO Classification of Tumours of the Central Nervous System となり，第 3 版を踏襲したかたちを取っている. 重要な変更点のうち神経膠腫に関する部分を列挙する と, 以下の 5 点になる ${ }^{13)}$.

腫瘍区分の明示：独立性が明らかな腫瘍群（腫瘍型 entity)，独立性が弱い腫瘍群（腫瘍亜型 variant）, 独立 性が不明な腫瘍形態像を取る群（腫瘍パターン pattern） の 3 区分を採用

Oligoastrocytoma の明示 : mixed tumor を oligoastrocytoma とした.

Glioblastoma の 2 subtype：遺伝子変異の相違により primary/secondary glioblastoma を記載

Glioblastoma with oligodendroglial components : glioblastoma の 1 pattern として掲載

WHO grading の継続: 腫瘍横断的な grading は臨床像と 対応している。つまり, pilocytic astrocytoma (WHO grade I ) と meningioma（WHO grade I ）は肉眼的全摘術に より治癒可能であることを意味している.

\section{WHO2016 神経膠腫分類の概要}

WHO2016 の consensus meeting は 2014 年，オランダ の Haarlemで行われ，改訂の方向性が示されている (Haarlem consensus) ${ }^{12)}$ 。その中で組織形態学 (histopathology), WHO grading, 分子情報（molecular informa- tion）を統合した integrated diagnosis を行うことを明示 している.

WHO2007 において神経膠腫は星細胞腫系，乏突起膠 腫系，乏突起星細胞腫系に分類されていたが，WHO2016 では乏突起星細胞腫系，すなわち oligoastrocytoma とい う分類が廃止され（Fig. 1)，まず分子情報をもとにして 星細胞腫系，乏突起膠腫系の 2 系統に分類する原則を とっている ${ }^{12)}$ 。これは診断上 oligoastrocytomaの腫瘍成 分比率がさまざまで, 診断者間のばらつきが大きいこ と 2)，分子情報をもとにすれば astrocytoma，oligodendroglioma が分類可能なことが判明してきたことによる7). 一方で，当該病変の WHO grade II，III，IVの分類は形態 学上の核異形，細胞異形，分裂像や分裂係数，血管内皮 の糸球体様変化で判定し，その grade を付記する ${ }^{12)}$.

診断にあたっては，まず isocitrate dehydrogenase （IDH）遺伝子変異を検討する。IDH 遺伝子変異群の約 90\%は IDH1 R132H の点突然変異であり，これは IDH1 抗体の免疫組織学的染色で検査可能であるが，それ以外 のまれな点突然変異は DNA シークエンスを用いた追加 検査が必要である6).

変異群のうち，星細胞腫系腫瘍は $\mathrm{p}-53$ タンパクを介 するシグナル系変異，乏突起膠腫系は $1 \mathrm{p} / 19 \mathrm{co}$-deletion が特徵となる。 p-53タンパクを介するシグナル系変異は 変異部位が多岐にわたつており，実地臨床上，その検索 が困難であるため，その surrogate maker としてp-53 夕 ンパクを介するシグナル系変異と相関性の高い $\alpha$-thalassemia/mental retardation syndrome X-linked (ATRX) 遺 伝子変異の検索が行われる ${ }^{712)}$. ATRX 遺伝子の変異は 免疫組織化学上，ATRX タンパク発現消失として認知さ 孔る ${ }^{6) 7}$. よって, IDH 遺伝子変異群のうち, 星細胞系腫 瘍は従来の形態学的特徵とともに分子情報として ATRX タンパク発現消失 (ATRX 遺伝子変異) が加わり, astrocytoma IDH mut. WHO grade II /III と表記され，glioblastoma の形態診断が下されれば glioblastoma IDH mut. WHO grade IV と表記される (Fig. 2 グレー部分 $)^{7) 12) .}$

また，細胞分裂ごとに生じる染色体断端（telomeres） 短縮を克服し，細胞を不死化する機構としてのヒトテロ メアーゼ逆転写酵素 (human telomerase reverse transcriptase：hTERT）の発現㐫進（遺伝子異常）と相互排他的 にATRX 遺伝子異常が観察されることが知られている (alternative lengthening of telomeres: ALT)。そのため hTERT 遺伝子異常の surrogate maker として ATRX 遺伝 子異常を把握することも理解を深める $(\text { Fig. 1 })^{6) 7112)}$.

IDH 変異群のうち，1p/19 co-deletion が証明された群 は従来の形態学的特徵を勘案し, oligodendroglioma $\mathrm{IDH}_{\mathrm{I}}$ mut. 


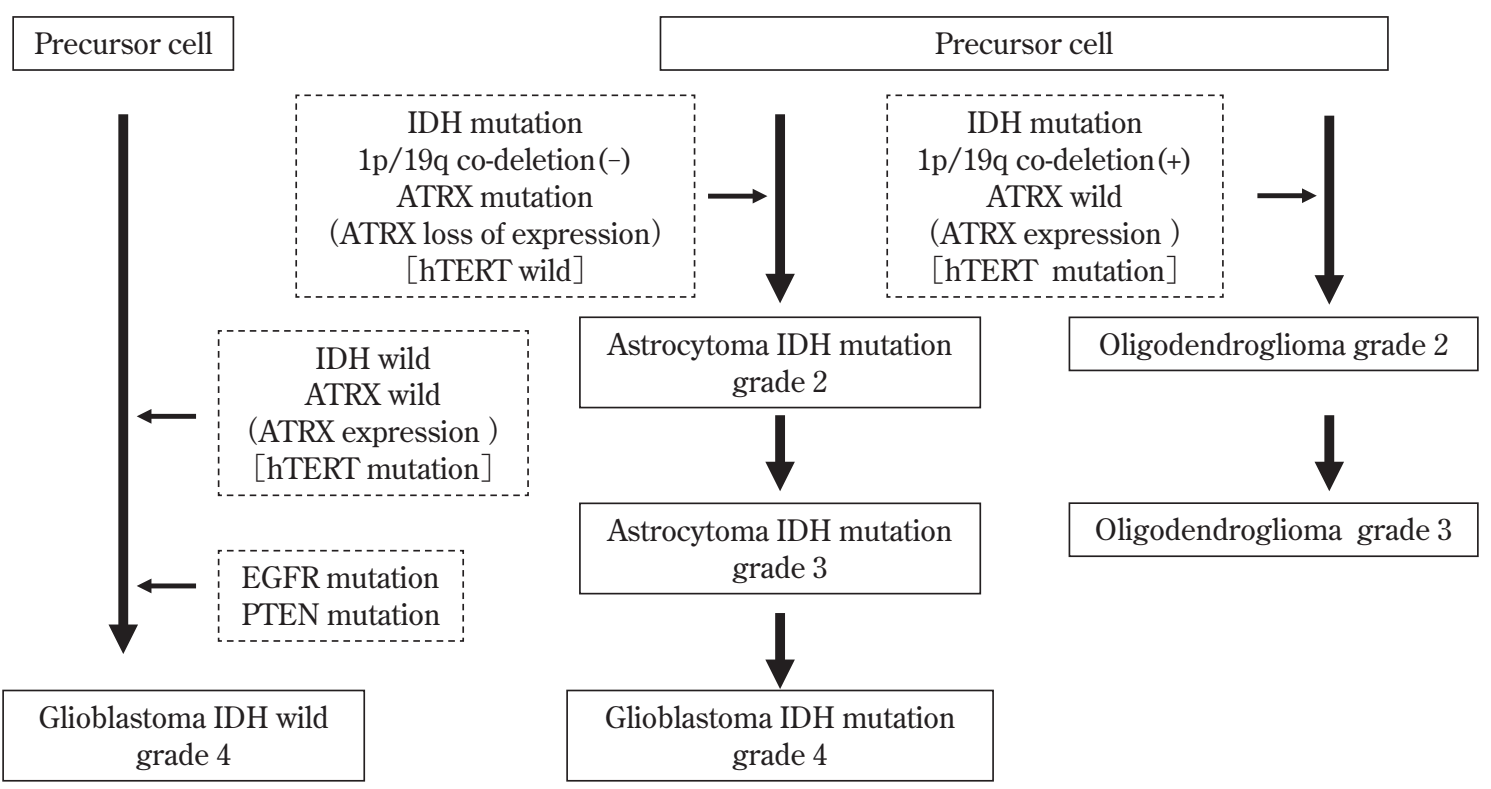

Fig. 1 Decision tree of diagnosis of adult gliomas based on molecular information (quoted from Ichimura $\mathrm{K}$, et al in reference \#6)

IDH : isocitrate dehydrogenase, ATRX : $\alpha$-thalassemia/mental retardation syndrome X-linked, hTERT : human telomerase reverse transcriptase, EGFR : epithelial growth factor receptor

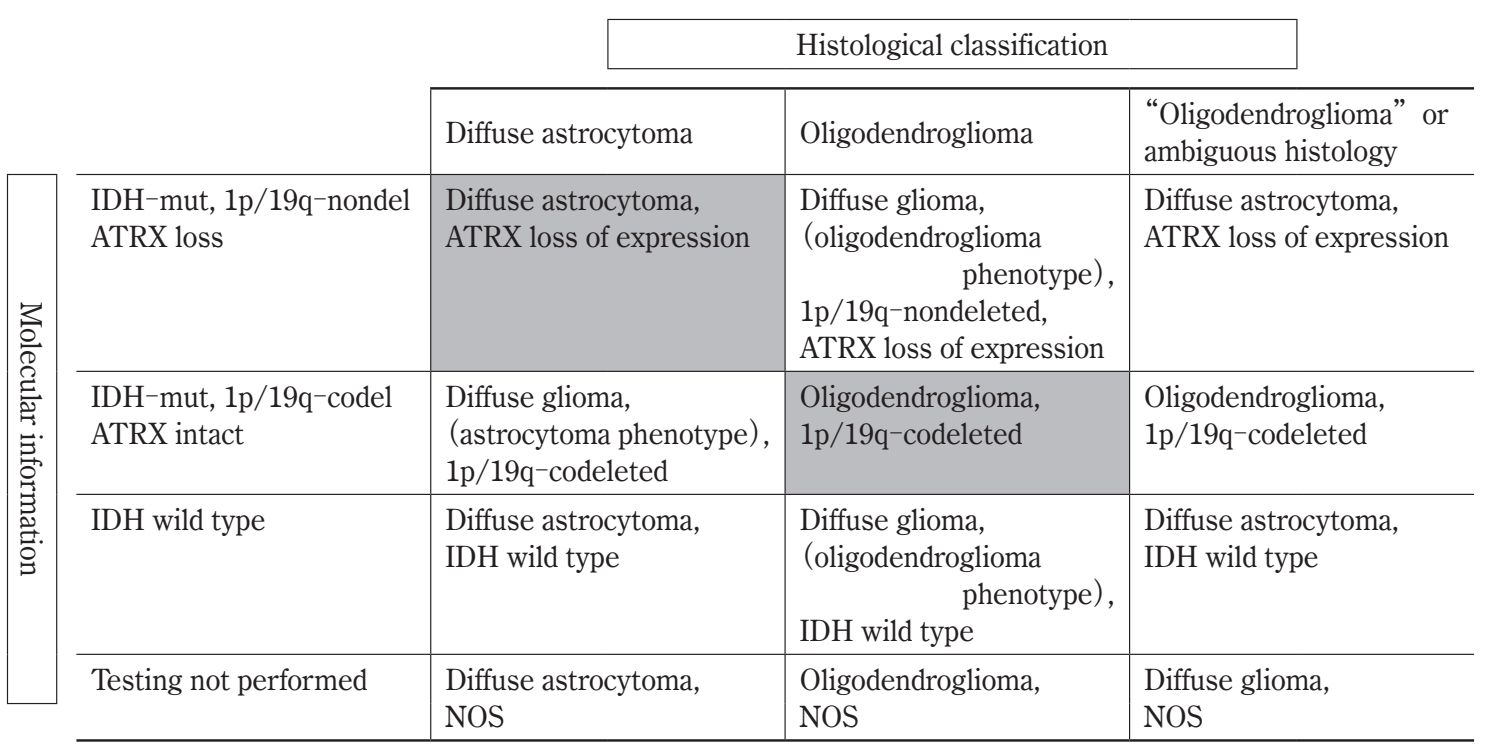

Fig. 2 Integrated diagnosis for WHO grade II / III adult gliomas based on Haarlem consensus (quoted from Louis DN, et al in reference \#12)

$\mathrm{IDH}$ : isocitrate dehydrogenase, ATRX : $\alpha$-thalassemia/mental retardation syndrome $\mathrm{X}$-linked, NOS : not other specified

Grade II /III と診断される. Grade IV相当の疾患概念は想 定されていない. (Fig. 2 グレー部分) ${ }^{12)}$.

分子情報と表現型が異なる場合は, まず diffuse glioma
と記載した後に diffuse glioma（astrocytoma phenotype）, 1p/19 co-deleted（1p/19 co-deletion を認めるが, 形態上 は astrocytoma), diffuse glioma (oligodendroglioma pheno- 
type), 1p/19 non-deleted, ATRX loss of expression（1p/ 19 deletion なし, ATRX タンパク発現消失ありだが, 形 態上は oligodendroglioma） と括弧内に個別情報を付帯し て診断とする $(\text { Fig. 2 })^{12)}$.

IDH wild type の場合は oligodendroglioma様の形態像で あれば, diffuse glioma (oligodendroglioma phenotype), それ以外であればたとえ oligoastrocytomaに類似してい ても diffuse astrocytoma と表記する（Fig. 2 IDH wild type 部分 $)^{12)}$.

分子診断を行っていない場合は「oligodendroglia, NOS $\lrcorner$ 「 astrocytoma, NOS $\lrcorner$ 「oligoasrtocytoma, NOS」 と NOS（not other specified）を後ろに付記する ${ }^{12)}$. さら には上記の分類に当てはまらない症例も指摘されてお り,このような症例の特異性を見極め, 専門検査施設に 迅速に照会する能力も臨床家として求められている.

Low grade astrocytomaの段階を経ることなく glioblastoma の形態診断を有する腫瘍を従来 primary glioblastoma と呼称していた。 この primary glioblastoma は IDH 遺伝子変異がなく, 上記の hTERT の発現立進が認めら れることが分子情報として重要であり, Haarlem consensus では glioblastoma IDH wild WHO grade IV と命名してい る ${ }^{12)}$ 。この腫瘍は同時に epithelial growth factor receptor 遺伝子変異, PTEN遺伝子変異が高率に認められること も特徵的である $(\text { Fig. 1 })^{6) 12)}$.

\section{おわりに}

脳腫瘍分類の歴史, WHO 脳腫瘍分類の変遷, WHO2016の神経膠腫分類の概要を述べた。WHO2016は integrated diagnosis，すなわち分子診断を重視した分類 であり，世界中の医療施設がこの分類を遂行可能かどう かは今後の検討が必要である。本邦においても FISH 検 査を必要とする $1 \mathrm{p} / 19 \mathrm{q}$ co-deletion 検索を院内のルーチ ン業務とするには多くの障壁があると予想される，名高 き人々から名高き分子たちと進んできた脳腫瘍分類は名 高き医療施設を求めるのだろうか? 今後の推移を見極 めたい.

本論文の主旨は第 35 回日本脳神経外科コングレス総会 (横 浜）で発表した。

著者の利益相反開示 : 著者は本論文の発表に関する利益相 反はない.

\section{文 献}

1) Agee J, Evans W : Let Us Now Praise Famous Men: The
American Classic, in Words and Photographs, of Three Tenant Families in the Deep South. New York, Mariner Books, 2001.

2) Ellison DE, Kocak M, Figarella-Branger D, Felice G, Catherine G, Pietsch T, Frappaz D, Massimino M, Grill J, Boyett JM, Grundy RG: Histopathological grading of pediatric ependymoma: reproducibility and clinical relevance in European trial cohorts. J Negat Results Biomed 10:7, 2011.

3）藤田尚男, 藤田恒夫: 組織学の研究法. 標準組織学 総論 第 3 版. 東京, 医学書院, 1988, pp.1-23.

4) Geyer JR, Zeltzer PM, Boyett JM, Rorke LB, Stanley P, Albright AL, Wisoff JH, Milstein JM, Allen JC, Finlay JL : Survival of infants with primitive neuroectodermal tumors or malignant ependymomas of the CNS treated with eight drugs in 1 day : a report from the Childrens Cancer Group. $J$ Clin Oncol 12: 1607-1615, 1994.

5）生田房弘：WHO の新しい脳腫瘍分類 1993 が生まれた前 後. Brain Nerve 46:1122-1125, 1994.

6）市村幸一, 有田秀之, 成田善孝: 遺伝子変異からみた神 経膠腫の発生機序。脳外誌 $23: 532-540,2014$.

7) Killela PJ, Reitman ZJ, Jiao Y, Bettegowda C, Agrawal N, Diaz LA Jr, Friedman AH, Friedman H, Gallia GL, Giovanella BC, Grollman AP, He TC, He Y, Hruban RH, Jallo GI, Mandahl N, Meeker AK, Mertens F, Netto GJ, Rasheed BA, Riggins GJ, Rosenquist TA, Schiffman M, Shih leM, Theodorescu D, Torbenson MS, Velculescu VE, Wang TL, Wentzensen N, Wood LD, Zhang M, McLendon RE, Bigner DD, Kinzler KW, Papadopoulos VBN, Yan H : TERT promoter mutations occur frequently in gliomas and a subset of tumors derived from cells with low rates of self-renewal. Proc Natl Acad Sci USA 110: 6021-6026, 2013.

8) Kleihues P, Burger PC, Scheithauer BW : Histological Typing of Tumours of the Central Nervous System. Berlin, SpringerVerlag, 1994.

9) Kleihues P, Cavenee WK : Pathology \& Genetics. Tumours of the Nervous System. Lyon, IARC Press, 2000.

10) Kleihues P, Lous DN, Ohgaki H, Wiestler OD, Cavenee WK : WHO Classification of Tumours of the Central Nervous System. Lyon, IARC Press, 2007.

11) Louis DN: The next step in brain tumor classification : "Let us now praise famous men" '. or molecules? Acta Neuropathol 124: 761-762, 2012.

12) Louis DN, Perry A, Burger P, Ellison DW, Reifenberger G, von Deimling A, Aldape K, Brat D, Collins VP, Eberhart C, Figarella-Branger D, Fuller GN, Giangaspero F, Giannini C, Hawkins C, Kleihues P, Korshunov A, Kros JM, Beatriz Lopes M, Ng HK, Ohgaki H, Paulus W, Pietsch T, Rosenblum M, Rushing E, Soylemezoglu F, Wiestler O, Wesseling $\mathrm{P}$; International Society of Neuropathology-Haarlem : International Society Of Neuropathology ${ }^{--}$Haarlem consensus guidelines for nervous system tumor classification and grading. Brain Pathol 24: 429-435, 2014.

13) 中里洋一: 脳腫瘍の新 WHO 分類. No Shinkei Geka 36 : 473-491，2008.

14) Rorke LB : The cerebellar medulloblastoma and its relationship to primitive neuroectodermal tumors. J Neuropathol Exp Neurol 42: 1-15, 1983.

15) Rubinstein LJ : Embryonal central neuroepithelial tumors and their differentiating potential. A cytogenetic view of a complex neuro-oncological problem. J Neurosurg 62 : 795805, 1985.

16) Russell SR, Rubinstein LJ : Pathology of tumours of the central 
nervous sytem. 5th ed. London, Arnold, 1989.

17) Scheithauer BW : Development of the WHO classification of tumors of the central nernous system : a historical perspective. Brain Pathol 19:551-564, 2009.

18）高倉公朋：脳腫瘍病理の歴史. 日本脳腫瘍病理学会編： 脳腫瘍臨床病理カラーアトラス 第 3 版，東京，医学書
院, 2009, pp.3-6.

19) Zülch KJ : Histological Typing of Tumours of the Central Nervous System.International Histological Classification of Tumors Geneva, WHO, 1979.

20) Zülch KJ : Brain Tumors. Their Biology and Pathology. 3rd ed. Berlin, Springer-Verlag, 1986.

要

旨

脳腫瘍分類の歴史と WHO2016 における神経膠腫診断の重要性

杉山一彦

WHO2007 までの脳腫瘍分類は Harvey W. Cushing, Lucien J. Rubinstein といつた著名な研究者が 中心となって, 形態学に基づいた分類を行ってきた. しかし, 近年脳腫瘍に関する分子情報が膨大に 蓄積され，これに基づく脳腫場分類の必要性が高まってきた．これらに対応するかたちで WHO2016 が策定されようとしている.

WHO2016 は integrated diagnosis を標榜しており, 組織形態学 (histopathology), WHO grading, 分子情報（molecular information）を総合して脳腫瘍診断を試みている．神経膠腫分野では oligoastrocytoma の概念が削除され，IDH 遺伝子変異, ATRX 遺伝子变異, 1p/19q 共欠失の 3 点の有無に基 づき, astrocytoma 系腫湯と oligodendroglioma 系腫湯に分類することが要点となっている. 